\title{
Leaching of Iron and Zinc into Food Simultant from Tin Can Packaging
}

\author{
Lilis Sulistiawaty, Imas Solihat, Arie Pratama Putra
}

Bogor AKA Polytechnic, Bogor,16680, Indonesia

Corresponding author: imaskhairani@gmail.com

Received: September 2019; Revision: November 2019; Accepted: November 2019; Available online: November 2019

\begin{abstract}
Cans are widely used as primary packaging in various food products. Ferrous ( $\mathrm{Fe}$ ) and zinc ( $\mathrm{Zn}$ ) metal as the constituent components in the manufacture of can packaging bodies can experience corrosion and dissolve in food so that it will affect food quality and finally affect to health. This study aimed to determine the content of Fe and $\mathrm{Zn}$ metal at different treatments (time) with 3\% acetic acid and vegetable oil as food simulators on can packaging using Atomic Absorption Spectrophotometer (AAS). The results of the analysis showed that the range of $\mathrm{Fe}$ and $\mathrm{Zn}$ metal content in $3 \%$ acetic acid food simulants were respectively $0.15-27.46 \mathrm{mg} / \mathrm{kg}$ and 0.0006 $0.007 \mathrm{mg} / \mathrm{kg}$, while in vegetable oil simulants $3 \% \mathrm{Fe}$ and metal content $\mathrm{Zn}$ were $0.6-2.46 \mathrm{mg} / \mathrm{kg}$ and $0.0004-$ $0.0025 \mathrm{mg} / \mathrm{kg}$ with $80-100 \%$ recovery, respectively. Thus, food from can packaging should not be exposed to oxygen for a long time, especially when it has been opened because it will increase the leaching of $\mathrm{Fe}$ and $\mathrm{Zn}$ metals from the packaging into food.
\end{abstract}

Keywords: Can packaging, food simulant, metal analysis.

DOI: $10.15408 / j k v \cdot v 5 i 2.12526$

\section{INTRODUCTION}

Tin cans are commonly used in products that undergo a thermal sterilization process. The advantages of can packaging are easy packaging, sterilization, delivery, transportation and minimized vitamin loss (Parkar J and Rakesh M, 2014). The disadvantage of can packaging is due to its non-inert property to chemicals which reacts with the environment and the contents causing loss of taste (Setyowati 2000).

Food products can experience interactions with cans at the time of storage which causes the transfer of packaging compounds into food products. Transfer of packaging components into food compounds that probably occurs is metal corrosion (AbdelRahman, 2015) such as zinc ( $\mathrm{Zn})$ and iron (Fe) because both metals are the compilers of can packaging (Syarief RS 1989). Iron (Fe) is used as a basic element in metal packaging while zinc $(\mathrm{Zn})$ is utilized to improve packaging resistance to corrosion (Cardeber et al, 2015). $\mathrm{Fe}$ and $\mathrm{Zn}$ metals are essential metals needed by the body, but the excessive amount of them will affect the quality of food and be harmful to health (Wagner, Castle, Oldring, Moschakis and Wedzicha, 2018). Excessive Fe metal will cause swelling in the liver and reduce the ability of the body to absorb copper, while excessive $\mathrm{Pb}$ metal will cause brain damage and nerve disorders.

The possibility of moving packaging components into food must be analyzed. Analysis using direct food is sometimes difficult to do because food products are a very complex matrix (McCort-Tipton and Pesseelman 1999). Therefore, to imitate certain food characteristics, a food simulation can be used (POM 2011). In this study, food simulants representing fatty and fatty foods used are $3 \%$ acetic acid and vegetable oil. According to Arora's research (2000), acidic foods such as tomatoes and tamarind juice with can packaging occur an increase in Fe metal content. Research by Parkar and Rakesh (2014) shows that Fe content increases in cans of orange juice contents with varied time and temperature. Therefore, research on the metal content in food simulants needs to be done because it deals with the migration of packaging components into food products. 


\section{MATERIALS AND METHODS Materials and Instrumentations}

The materials used in this study were standard pure analysis, distilled water, Nitric acid $\left(\mathrm{HNO}_{3}\right)$ merck KgaA, Hydrogen Peroxide $\left(\mathrm{H}_{2} \mathrm{O}_{2}\right) 30 \%$ merck KgaA, Standard solution Fe $1000 \mathrm{ppm}$, Standard solution of Zn 1000 ppm (CertiPUR Merck KgaA), Tin cans, Vegetable oil and Acetic acid 30\%.

Glass Tools, Flame-AAS type Shimadzu AA 2000, Hollow cathode lamp Fe and Zn, Oven, Desiccator, Analytical balance and Close microwave digestion type MDS 6G SINEO.

\section{Physical Analysis of Can Packaging}

The can packaging used in this study was the can packaging for sardines obtained from the market with the same identity (batch number and expiration date). Intact cans were opened and poured its contents into a tub, then the cans were cleaned and dried. Clean cans were measured the dimensions and enamel coating uniformity.

Dimension measurement of fish cans including the inner diameter, outer diameter, depth and thickness of the cans using calipers. The test was carried out on 3 cans. The uniformity of the enamel coating was conducted on 3 cans by cutting the $1.5 \mathrm{~cm} \mathrm{x}$ $1.5 \mathrm{~cm}$ can plate and then immersed in the test solution (destilled water: copper sulfate: $\mathrm{HCl}$ with a ratio of 70:20:10) for 2 minutes at room temperature. The plate was washed with clean water and then observed.

\section{Elemental Analysis}

Clean and dry cans were filled with food simulants $\pm 150 \mathrm{~mL}$ (3\% acetic acid and vegetable oil) and sealed with polyethylene plastic. Food simulants were stored at $38{ }^{\circ} \mathrm{C}$ with a variation of time $(0,2,4,6,8,10,12)$ weeks and measurements of $\mathrm{Fe}$ and $\mathrm{Zn}$ metal content in food simulations was conducted by using AAS machine.

The destruction process was carried out using the microwave digestion method. The food simulant sample was weighed as much as 0.5 gram using an analytical balance, then the sample was put into a vessel tube. The vessel tube containing the sample was added 7

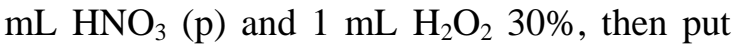
into the Microwave Digestion. After the digestion process was complete, the solution was left until it reached room temperature, then the solution was transferred to a $50 \mathrm{~mL}$ measuring flask, and fulfilled with double distilled water and homogenized. A blank solution with the addition of reagents was prepared and the same treatment was applied as the example. Microwave digestion settings can be seen in Table 1 .

Table 1. Setting digestion with microwave digestion

\begin{tabular}{cccc}
\hline Stage & Temp $\left({ }^{\circ} \mathbf{C}\right)$ & $\begin{array}{c}\text { Time } \\
(\text { Minute) }\end{array}$ & Power $(\mathbf{W})$ \\
\hline 1 & 130 & 10 & 300 \\
2 & 150 & 5 & 600 \\
3 & 180 & 15 & 500 \\
\hline
\end{tabular}

\section{Testing Analytical Methods \\ Precision and Accuracy}

This test was carried out using a sample that was added (spiking) with a standard solution of seven replications. Spiking was done at the beginning of sample preparation before being treated with microwave digestion. Each spiking was done by seven replications. Accuracy was determined by calculating The recovery percentage (recovery).

Precision was determined by comparing the RSD value of the analysis with the RSD Horwitz. Precision was said to be good if it had an RSD analysis value < 2/3 CV Horwitz.

\section{Linearity}

Testing the linearity of $\mathrm{Fe}$ mineral with concentration of $0-0.5 \mathrm{mg} / \mathrm{L}$ while $\mathrm{Zn}$ mineral concentration was of $0-1.0 \mathrm{mg} / \mathrm{L}$. Each of the standard solutions was measured by absorbance repeated 3 times. Linearity was considered good if it had a correlation coefficient (r) more than 0.995 or $\mathrm{R}^{2}$ more than 0.990 .

\section{RESULTS AND DISCUSSION Physical Analysis of Can Packaging Measurement of can dimension}

Tin cans used were round cans. A round can was a type of can that is physically circle or round with its constituent elements in the form of body and end components. The measurement results of can dimension can be seen in Table 2. 
Table 2. Measurement results of can dimension

\begin{tabular}{ccccc}
\hline Replication & Inner Diameter $(\mathbf{c m})$ & Outer Diameter $(\mathbf{c m})$ & Depth $(\mathbf{c m})$ & Thickness $(\mathbf{c m})$ \\
\hline 1 & 4.695 & 5.270 & 8.590 & 0.575 \\
2 & 4.725 & 5.225 & 8.595 & 0.550 \\
3 & 4.835 & 5.260 & 8.465 & 0.575 \\
\hline
\end{tabular}

\section{The Uniformity of The Enamel Coating}

The enamel coating is a non-metallic coating on cans that coat metal (prevents corrosion) and protects direct contact with the product. Inner enamel serves to prevent metal contact with food, minimize interactions between food and packaging such as sulfide staining reactions while outer enamel serves to prevent corrosion caused by the environment and for decoration. The results of the analysis of the uniformity of the enamel coating can be seen in Table 3. The interaction between food compounds and packaging can cause corrosion resulting in unwanted color and flavor, including the formation of a black color caused by the reaction between iron or lead with sulfide in low-acidic (high protein) food, and red pigment bleaching from vegetables/fruits such as beets or grapes due to reactions with steel, lead or aluminum.

Table 3. Results of analysis of enamel coating uniformity testing

\begin{tabular}{|c|c|c|c|c|}
\hline \multirow{2}{*}{$\begin{array}{l}\text { Testing } \\
\text { Media }\end{array}$} & \multirow[b]{2}{*}{ Treatment } & \multicolumn{3}{|c|}{ Result } \\
\hline & & $\begin{array}{l}\text { Black } \\
\text { Stain }\end{array}$ & Reddish & Scratch \\
\hline $\begin{array}{l}\text { Can } \\
\text { plate } \\
\text { with the } \\
\text { size of } \\
1.5 \times 1.5 \\
\mathrm{~cm}\end{array}$ & $\begin{array}{l}\text { Aquadest: } \\
\text { copper } \\
\text { sulfate:HCl }\end{array}$ & $\sqrt{ }$ & $\mathrm{x}$ & $\mathrm{x}$ \\
\hline
\end{tabular}

From the results of observations, it was seen that the inner layer that was not given enamel occurred corrosion because the metals contained in the inside of the could react with food, especially food containing acid. On the outer layer, there were black spots (corrosion) on the edges because there was a reaction between iron or tin with $\mathrm{Cu}$. Enamel was used to prevent corrosion on the inside and outside of the can.

Corrosion is a defect in the form of rust (black spots) caused by the chemical reaction process which was corrosive, both water and acid. Generally, the material that is not coated with enamel is easily exposed to acidic chemicals or humid air, so that it causes oxidation reactions resulting in further rust.

\section{Elemental Analysis}

Metal measurement was carried out using the microwave digestion method. This method has several advantages compared to conventional digestion (wet and dry digestion). Some of them are: the reagent used is lesser and it processes in faster time (Altundag and tuzen, 2011; Mustafa et al., 2003; 2004; Korn et al., 2008). A sample with high oil content only requires a small amount of sample, but a sample with high water content requires a higher amount sample (Mindak et al., 2010).

The advantages of can as food and drink packaging are its high mechanical strength, good barrier against gas, steam, water, microorganisms, dust and dirt making it suitable for hermetic packaging. The toxicity is relatively low although there is a possibility of metal elements migration into the packaged material. It is resistant to changes or extreme temperature conditions. In addition, it has an ideal surface for decoration and labeling (Syarief et al., 1989).

The occurrence of displacement of packaging components into food is influenced by several factors, including the initial concentration of food contact substances, the time length of the packaging contacts with food, contact temperature, surface area and food properties (acidic, fatty, alcoholic) (BPOM 2009). In this study, the total immersion test method was used due to its simplicity, it was done by making contact between the food simulants and the entire surface of the package. The mechanism for releasing packaging components can be done in 4 ways as shown in Figure 1, namely (a) direct contact with the package, (b) indirect contact from the packaging as a secondary material, (c) from the outside of packaging and (d) from the packaging matrix to the outside environment. 


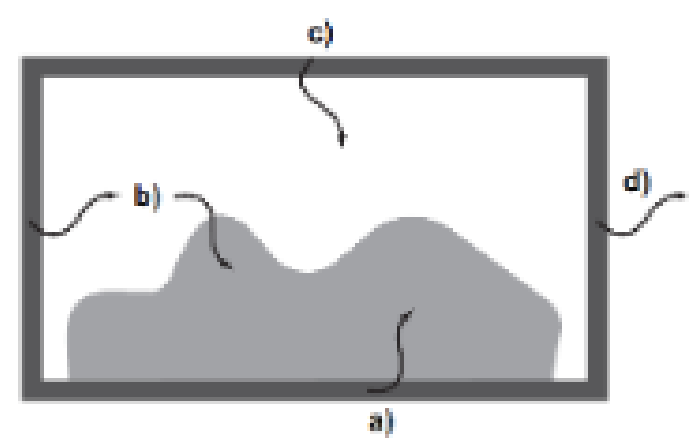

Figure 1. The mechanism of releasing packaged food components (Pocas et al., 2011).

Zinc $(\mathrm{Zn})$ is often used in metal packaging to increase the resistance of lead and steel from corrosion (Mousawi et al., 2018). In this research, 3\% acetic acid food simulants were used to represent acidic foods and vegetable oils represent foods with high-at content, with the consideration that cans are widely used for fatty and fatty foods such as acidic drinks, juices and canned fish packaging. The use of food simulants was intended as a substitute for food because food products are a very complex matrix.

The results of the migration of $\mathrm{Fe}$ and $\mathrm{Zn}$ metal can be seen in Figure 2. From the analysis results, it was obtained that the levels of $\mathrm{Fe}$ and $\mathrm{Zn}$ metal were increasing, especially in acid food simulants. The results of the analysis were still below the range of the standard specific release limits (SRL) set by the Council of Europe resolution CM/Res (2013) in which the SRL for Fe metal is 40 $\mathrm{mg} / \mathrm{kg}$ and $\mathrm{Zn}$ metal is $5 \mathrm{mg} / \mathrm{kg}$. According to Laroussen and Brown (1997), the longer food is stored, the longer the contact time between

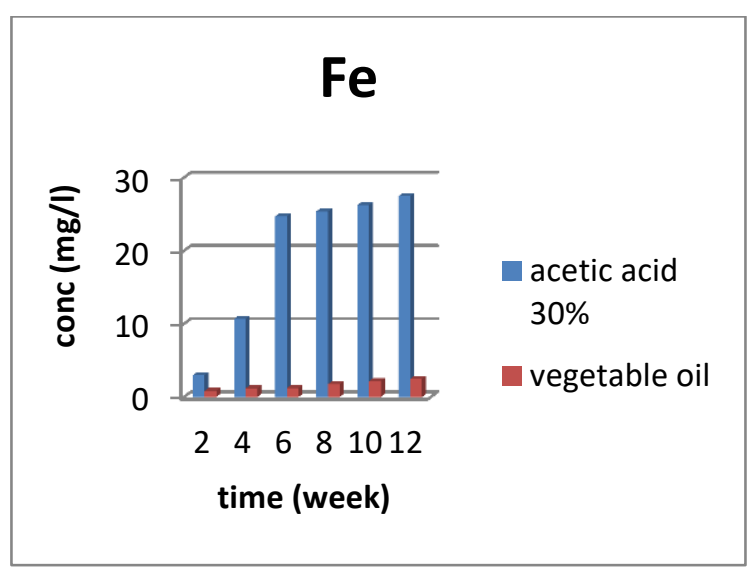

Figure 2. Leaching metal $\mathrm{Fe}$ and $\mathrm{Zn}$ in food simulant food and container, then the greater the possibility of the metal constituent to be separated and contaminate the packed food.

This shows that the use of tin cans should not interact with oxygen for too long especially if the food sample is acidic because it will result in the migration of $\mathrm{Fe}$ metal. Some factors determining the formation of rust on the inside of the can include the nature of food ingredients, especially $\mathrm{pH}$; promoters of rust formation such as nitrates (found in some fruits and vegetables); the amount of oxygen remaining in food, especially in the remaining space; temperature and storage time; as well as several factors derived from packaging materials, such as the weight of the tin layer, the composition of the base steel layer, the effectiveness of the treatment on the surface of the layer, the type of coating, etc. (Julianti and Nurminah, 2006; Laroussen and Brown, 1997). The presence of gas in can is caused by hydrogen production due to corrosion (Dantas, 2016).

Migration of metal packaging will affect the quality (aroma, taste and color) and safety (accumulation of migrant substances). Rust formation occurs because the tin layer is peeled or dissolved into the food simulant so that the metals contained in the inner compartment of the can react and contaminate the food simulant (Itodo and Itodo, 2010). According to $\mathrm{FAO} / \mathrm{WHO}$, the maximum limit of iron content in food is $250 \mathrm{ppm}$. Metal poisoning can be mild or severe poisoning such as nausea, vomiting, dizziness and excessive cold sweating (Syarief et al., 1989).

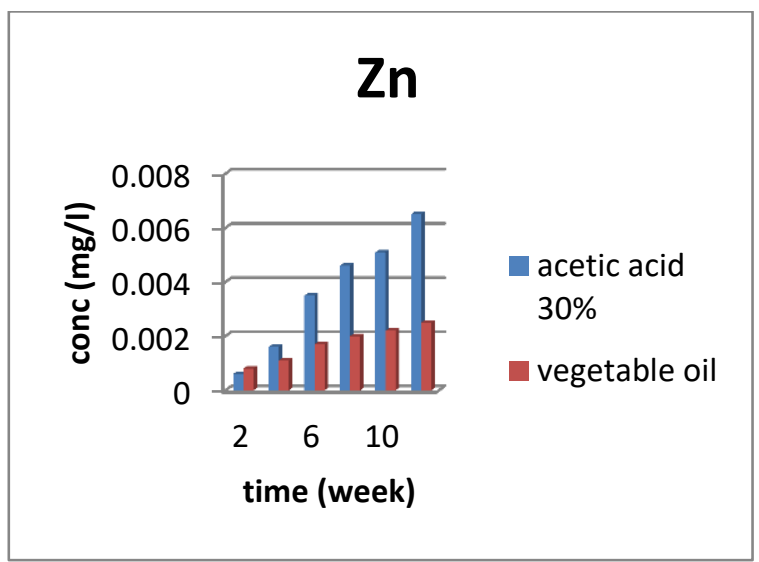




\section{Testing Method of Analysis}

Table 4 . Precision analysis result

\begin{tabular}{|c|c|c|c|c|c|c|c|c|c|c|c|c|}
\hline & \multicolumn{12}{|c|}{ \% Recovery Metal Fe } \\
\hline & \multicolumn{6}{|c|}{ Acetic acid 30\% } & \multicolumn{6}{|c|}{ Vegetable oil } \\
\hline \multirow{3}{*}{$\overline{\boldsymbol{x}}$} & 2 & 4 & 6 & 8 & 10 & 12 & 2 & 4 & 6 & 8 & 10 & 12 \\
\hline & 84.29 & 109.88 & 90.37 & 81.33 & 80.32 & 86.92 & 100.23 & 98.81 & 103.66 & 82.86 & 84.69 & 86.88 \\
\hline & & 8 & 7 & 3 & 2 & & & 1 & 6 & & 9 & 8 \\
\hline \multicolumn{13}{|c|}{ \% Recovery Metal Zn } \\
\hline & \multicolumn{6}{|c|}{ Acetic acid 30\% } & \multicolumn{6}{|c|}{ Vegetable oil } \\
\hline \multirow{3}{*}{$\bar{x}$} & 2 & 4 & 6 & 8 & 10 & 12 & 2 & 4 & 6 & 8 & 10 & 12 \\
\hline & 82.02 & 82.14 & 82.12 & 80.25 & 81.87 & 82.14 & 79.68 & 83.94 & 87.26 & 90.58 & 94.38 & 98.64 \\
\hline & 2 & & 2 & 5 & 7 & & & 4 & & & 8 & 4 \\
\hline
\end{tabular}

Table 5. Accuracy analysis result

\begin{tabular}{|c|c|c|c|c|c|c|c|c|c|c|c|c|c|c|}
\hline \multicolumn{15}{|c|}{ Fe Content (mg/L) } \\
\hline \multicolumn{8}{|c|}{ Acetic acid 30\% } & \multicolumn{7}{|c|}{ Vegetable oil } \\
\hline & 0 & 2 & 4 & 6 & 8 & 10 & 12 & 0 & 2 & 4 & 6 & 8 & 10 & 12 \\
\hline Average & 0.15 & 2.97 & 10.66 & 24.70 & 25.37 & 26.23 & 27.46 & 0.60 & 0.83 & 1.19 & 1.20 & 1.75 & 2.17 & 2.46 \\
\hline$\%$ RSD & 8.65 & 2.50 & 0.79 & 1.30 & 0.25 & 0.02 & 0.37 & 8.90 & 8.65 & 2.65 & 14.85 & 6.11 & 0.83 & 2.42 \\
\hline $\begin{array}{l}2 / 3 \\
\mathrm{RSDH}\end{array}$ & 14.17 & 9.06 & 7.47 & 6.58 & 6.56 & 6.52 & 6.48 & 11.51 & 10.98 & 10,39 & 10.38 & 9.80 & 9.49 & 9.32 \\
\hline \multicolumn{15}{|c|}{ Zn Content (mg/L) } \\
\hline Average & $\begin{array}{c}6 \\
\times 10^{-4}\end{array}$ & $\begin{array}{c}1.6 \\
\times 10^{-3}\end{array}$ & $\begin{array}{c}3.5 \\
\times 10^{-3}\end{array}$ & $\begin{array}{c}4.6 \\
\times 10^{-3}\end{array}$ & $\begin{array}{c}5.1 \\
\times 10^{-3}\end{array}$ & $\begin{array}{c}6.5 \\
\times 10^{-3}\end{array}$ & $\begin{array}{c}7 \\
\times 10^{-3}\end{array}$ & $\begin{array}{c}4 \\
\times 10^{-3}\end{array}$ & $\begin{array}{c}8 \\
\times 10^{-4}\end{array}$ & $\begin{array}{c}1.1 \\
\times 10^{-3}\end{array}$ & $\begin{array}{c}1.7 \\
\times 10^{-3}\end{array}$ & $\begin{array}{c}2 \\
\times 10^{-3}\end{array}$ & $\begin{array}{c}2.2 \\
\times 10^{-3}\end{array}$ & $\begin{array}{c}2.5 \\
\times 10^{-3}\end{array}$ \\
\hline$\%$ RSD & 21.65 & 8.66 & 7.87 & 2.99 & 2.71 & 2.11 & 1.97 & 34.64 & 17.32 & 24.74 & 24.74 & 27.71 & 24.74 & 22.35 \\
\hline $\begin{array}{l}2 / 3 \\
\text { RSDH }\end{array}$ & 32.32 & 28.16 & 25.01 & 23.99 & 23.64 & 22.77 & 22.53 & 34.69 & 31.25 & 29.71 & 27.95 & 27.23 & 26.77 & 26.36 \\
\hline
\end{tabular}

\section{Linearity}

The resulting regression equation for the mineral $\mathrm{Fe}$ was $\mathrm{y}=0.084 \mathrm{x}-0.0002$ with $\mathrm{R}^{2}=$ 0.9970 ; mineral $\mathrm{Zn}$ was $\mathrm{y}=0.4125 \mathrm{x}+0.0086$ with $R^{2}=0.9977$. The linearity curve obtained has an $\mathrm{R}^{2}$ value of more than 0.990 indicating a direct correlation between the concentration of the standard series and absorbance.

\section{Precision}

The results of the precision test can be seen in Table 4. From this table, it can be seen that the precision for the mineral $\mathrm{Fe}$ and $\mathrm{Zn}$ produces a value of $\%$ RSD $<2 / 3$ CV Horwitz. This indicates that the results of the analysis are precise and there are no random errors.

\section{Accuracy}

Accuracy aims to see the efficiency of the method based on recovery of standard solutions added to the sample (spiking) (Ajai $e t$ al., 2014). The test results for the accuracy of $\mathrm{Fe}$ and $\mathrm{Zn}$ mineral can be seen in Table 5. The recoveries produced from $\mathrm{Fe}$ metal was in the range of $80-102 \%$, these results are still within the acceptability limit of AOAC, which is around $80-120 \%$. This indicates that the analysis procedure with the modified method for all minerals can be accepted. The accuracy obtained did not differ greatly from the results of the analysis of Ajai et al., (2014) in canned pineapple samples with a recovery of $80 \%$. Accuracy is related to systematic error that can be controlled. Sources of systematic error include the use of glass tools that have not been calibrated.

\section{CONCLUSION}

The content of $\mathrm{Fe}$ and $\mathrm{Zn}$ metal in the acetic acid food simulants of $3 \%$ is more than the vegetable oil simulations. This is because the acid content is easier to cause corrosion on cans and is accelerated in the presence of oxygen. Therefore, food from tin cans is sought not to be exposed to oxygen for a long time especially when it has been opened.

\section{ACKNOWLEDGMENTS}

Bogor AKA Polytechnic as a place to conduct research and as a financial supporter of this research. 


\section{REFERENCES}

Abdel-Rahman NA. 2015. Tin-plate corrosion in canned foods. Journal of Global Biosciences. 4(7): 2966-2971.

[BPOM] Badan Pengawas Obat dan Makanan. 2011. Peraturan Kepala Badan POM Nomor HK.03.1.23.07.11.6664 Tahun 2011 tentang Pengawasan Kemasan Pangan. Jakarta: BPOM.

[BPOM] Badan Pengawas Obat dan Makanan. 2011. Laporan Kajian Risiko Zat Kontak Pangan Berisiko Tinggi. Jakarta : BPOM.

Ajai AI, Ochigbo SS, Anigboro PI. 2014. Determination of trace metals and essensial minerals in selected fruit juices in Minna, Nigeria. International Journal of Food science. ID 462931.

Altundag, H., Tuzen, M., 2011, Comparison of dry, wet and microwave digestion method for the multi element determination in some dried fruit samples by ICP-OES. Food Chem.Toxicol, 49: 2800-2807.

AOAC. 1995. Official Methods of Analysis of The Association of Official Agriulture Chemist. AOAC Inc. WashingtoN.

Arora A. 2000. Total and ionisable iron content in some vegetables as influenced by cooking in iron utensil. Journal of food science and technology. 37(1): 64-66.

Cederber DL, Ekorth S, Engman J, Fabech B, Tesdal J, Kostaomo P, Legind C, Svensson K. 2015. Food contact materials-metals and alloys. Nordic guidance for authorities, industry and trade. Vol. 2015522. Nordic Council of Ministers.

Council of Europe (2013). Committee of Experts on Packaging Materials for Food and Pharmaceutical Products. Metals and Alloys Used in Food Contact Materials and Articles: A Practical Guide for Manufacturers and Regulators. European Directorate for the Quality of Medicines \& HealthCare (EDQM).

Dantas FBH, Dantas ST. 2016. Canned food and packaging parameters. Reference moduls in food sciences. Institutr of food technology.

Itodo AU, Itodo HU. 2010. Quantitative specification of potentialy toxic metals in expired caned tomatoes founds in villages market. Nature and science. 8(4):54-58.

Julianti E, M Nurminah. 2006. Buku Ajar Teknologi Pengemasan. Medan: Departeman Teknologi Pertanian, Universitas Sumatera Utara.

Korn MGA, Morte ESB, Santos DCMB, Castro JT, Barbosa JTP, Teixeira AP. 2008. Sample preparation for the determination of metals in food samples using spectroanalytical methods, Journal Applied Spectroscopy Review. 43(2): 67-92.

Larousse J, Bruce EB. 1997. Food Canning Technology. Wiley-VCH, Inc. USA

McCort-Tipton M, Pesselman RL. 1999. What Simulant is Right for My Intended End Use?. Di dalam: Food Packaging. Testing Methods and Applications. (S. J. Risch, ed.). American Chemical Society, Washington DC.

Mindak WR, Cheng J, Jacobs RM. 2010. Elemental Analysis Manual: Section 2.3 analytical portion to analytical solution. 9 Januari 2011.

http://www.fda.gov/Food/ScienceResearch /LaboratoryMethods/ElementalAnalysisM anualEAM/ucm195383.htm.

Mustafa T, Hayati S, Mustafa S. 2004. Microwave and wet digestion procedures for atomic absorption spectrometric determination of trace metals contents of sediment samples. Anal Lett. 37(9): 1925-1936.

Mustafa T, Ibrahim T, Erdoğan H, Durali M, Hayati S. 2003. Atomic absorption spectrometric determination of trace metal contents of mushroom samples from Tokat, Turkey. Anal Lett. 36(7): 1401-1410.

Parkar J, Rakesh M. 2014. Leaching of elements from packaging material into canned foods marketed in India. Food Control. 40(2014): 177-184.

Poças MFF, Jorge CO, Joel RP, Rainer B, Timothy H. 2011. Modelling migration from paper into a food simulant. Food Control. 22: 303-312.

Sara NEM, Rosette O, Joseph M, Hanna C, Mathieu C, Valérie. 2019. Simultaneous migration of bisphenol compounds and trace metals in canned vegetable food. Journal Food Chemistry. 288(2019): 228- 
238

doi:https://doi.org/10.1016/j.foodchem.201 9.02 .

Setyowati K. 2000. Pengemasan I. Departemen Teknologi Industri Pertanian. FATETA. IPB.Bogor.

Syarief, Rizal S. Santausa, Isyana S. 1989. Teknologi Pengemasan Pangan.
Laboratorium Rekayasa Bioproses Pangan. PAU IPB. Bogor.

Wagner J, Castle L, Oldring PKT, Moschakis T, Wedzicha BL. 2018. Factors affecting migration kinetics from a generic epoxyphenolic food can coating system. Food Research International. 106: 183-192. http://doi.org/10.1016/j.foodres.2017.12.0 59. 